\title{
BIOCHEMICAL DIFFERENTIATION OF THE SIBLING BLACK WIDOW SPIDERS, LATRODECTUS MACTANS AND L. VARIOLUS*
}

\author{
By John D. McCrone \\ Department of Zoology, University of Florida
}

A recent revision of the black widow genus Latrodectus published by Levi (1959) has stimulated a great deal of interest in this medically important group of spiders and has served as the basis for several subsequent investigations in various parts of the world (Abalos, I962; McCrone and Levi, I964; Szlep, I965; Levi, I966). All of these have shown that several species which are virtually indistinguishable morphologically can readily be separated on the basis of various aspects of their biology. These findings in turn have led students of the group to seek additional taxonomic characters for use in the separation of these species.

Rabaey and Verriest (1958) after a survey of the comparative agar gel microelectrophoretic patterns of the hemolymphs of 33 species of spiders, exclusive of any Latrodectus species, concluded such patterns could be very useful for the differentiation of species, particularly those within the same genus. Encouraged by their results, I decided to determine whether a technique of this type would provide useful taxonomic information in the genus Latrodectus.

This investigation was supported by Public Health Service Research Grant GMiı206 from the National Institute of General Medical Sciences. I wish to thank Miss Marietta Marra and Mr. Paul Dell for their technical assistance.

\section{Materials and Methods}

An increasing number of electrophoretic techniques have become available in recent years including agar, starch, disc and vertical acrylamide gel electrophoresis. All of the latter have been used to some extent in evolutionary and taxonomic studies (Manwell and Baker, 1963; Hubby, 1963; Hubby and Throckmorton, 1965; Coates, I967) and have given satisfactory results. I have found, as did Hubby (1965), that the vertical acrylamide gel technique gives particularly good results. The acrylamide gel slab is much easier to handle than the starch gel and there is comparable resolution. Disc

*Manuscript received by the editor May 15, 1967 


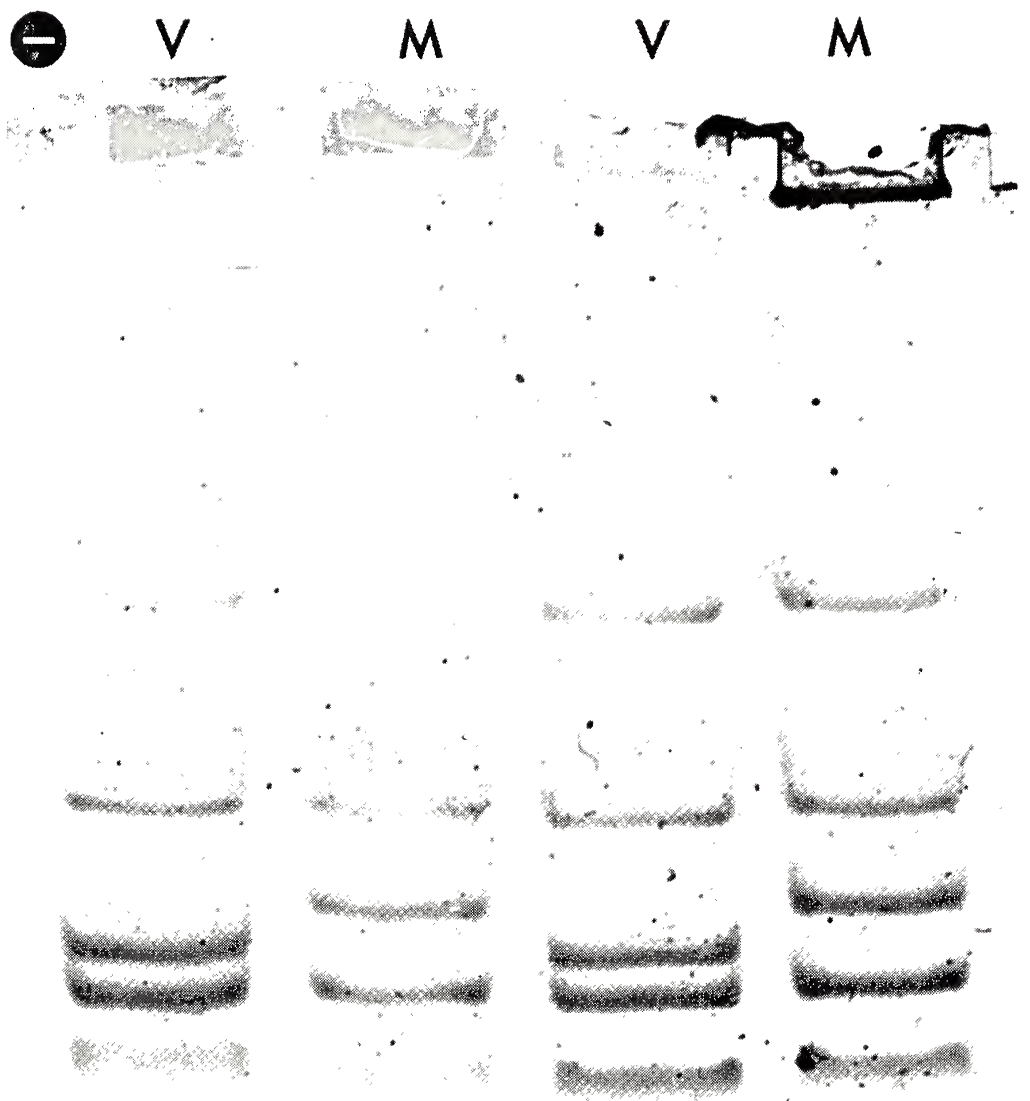

$\oplus$

Figure 1. Vertical acrylamide gel electrophoretic patterns of the hemolymph proteins of female Latrodectus mactans (M) and L. variolus (V).

electrophoresis also gives excellent resolution but is less useful for taxonomic comparisons because it is difficult to run standard reference proteins as controls in the same gels as the samples. In the case of Latrodectus hemolymph there is the additional advantage that the hemolymph from a single spider will form a distinct pattern in a single slot when the 8-slot slab is used. This allows a determination 
of the amount of variability between the patterns of individual spiders.

The spiders used in this study were mature females of the sibling species Latrodectus mactans (Fabricius) and Latrodectus variolus Walckenaer collected in Florida during the summer at St. Petersburg and Torreya Ravine State Park respectively. These females are very difficult to separate using conventional morphological criteria.

Hemolymph was obtained from individual spiders by severing the legs at the junction of the coxa and trochanter and then drawing up the expressed hemolymph into a polyethylene capillary tube connected to a I cc hypodermic syringe. The hemolymph was then mixed with $0.05 \mathrm{ml}$ of a Karo syrup - buffer solution (9 parts Tris buffer $\mathrm{pH}$ 9.0: I part Karo syrup). The Karo increased the density of the solution making it easier to layer the sample into the gel shots.

The electrophoretic runs were carried out in a cell manufactured by the E-C Apparatus Corp. in which a 8-slot, 8 per cent acrylamide gel slab was used. The hemolymph sample from each spider was loaded into one of 6 slots, the other 2 slots were loaded with $0.1 \mathrm{ml}$ of a solution of human serum albumin $(0.05 \mathrm{mg} / \mathrm{ml})$. The albumin solution was lightly stained with bromthymol blue so that its migration could be followed. Tris buffer $(\mathrm{pH} 9.0)$ was used in the buffer compartments of the cell and 150 ma $(560-780 \mathrm{oV})$ was applied for $90 \mathrm{~min}$. The gel slab was then stained with amido schwarz and the relative mobility of each of the hemolymph protein fractions was obtained by comparing its mobility to that of the human serum albumin.

\section{Results}

The individual electrophoretic patterns of the hemolymph proteins of Io L. mactans and I I $L$. variolus females were recorded. Five fractions were found in each species and the average relative mobility of each of these fractions is given in Table I. Each fraction is numbered relative to its position from the origin, fraction I being the closest to the origin. Figure I shows the characteristic patterns of the two species. All were run in the same gel. There are no significant differences in the average relative mobilities of fractions I, 2, 4 and 5 in the two species, but there is a clear cut difference in those of fraction 3. The magnitude of the difference is such that the relative mobility of this fraction can be used to separate all tested females of the two species. 


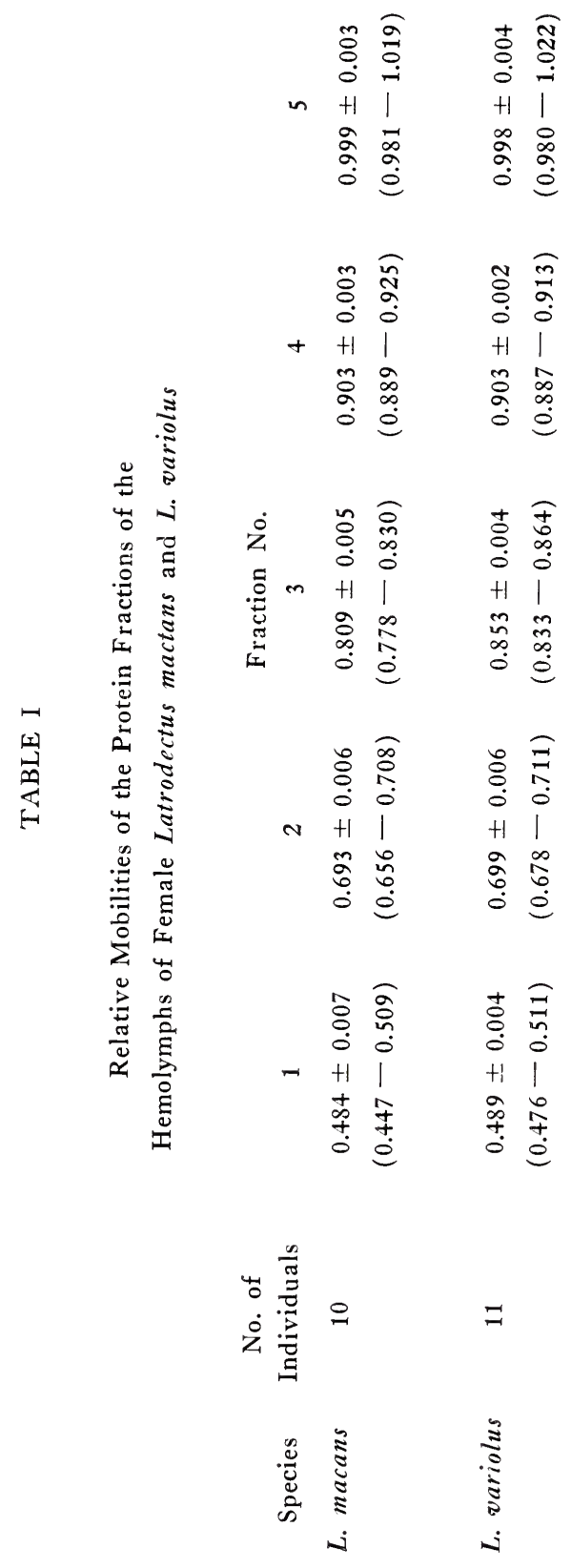




\section{Conclusions}

The vertical acrylamide gel electrophoretic patterns of the hemolymph proteins provide an excellent taxonomic character for the separation of the two sibling species $L$. mactans and $L$. variolus, at least in one geographic area, and this technique should prove useful in further systematic studies of the genus Latrodectus. Its usefulness would be considerably enhanced if we had additional information on geographic variation in this character and knowledge of the functional nature of the various protein fractions from the hemolymph, particularly that of fraction 3. Unfortunately little is known about the biochemistry of spider hemolymph and even less about that of Latrodectus species. Boyd (I937) published serological evidence for the presence of hemocyanin in Latrodectus and Finlayson (1937) reported the presence of a protein-like, toxic substance he called arachnolysin.

Abalos, J. W.

\section{Literature Cited}

1962. The egg sac in the identification of species of Latrodectus (Black BOYd, W. C. Widow Spiders). Psyche, 69: 268-270.

1937. Cross-reactivity of various hemocyanins with special reference to the blood proteins of the black widow spider. Biol. Bull., $73(1): 181-183$.

Coates, $M$.

1967. A comparative study of the serum proteins of the species of Taricha and their hybrids. Evolution, 21(1): 130-140.

Finlayson, M. H.

1937. Some properties of the venom and arachnolysin of $L$. indistinctus. S. Afr. J. Med. Sci., 2 (4) : 151-155.

HUBby, J. L.

1963. Protein differences in Drosophila I. Drosophila melanogaster. Genetics, 48 (6) : 871-879.

HubBy, J. L. AND H. H. Throckmorton.

1965. Protein differences in Drosophila II. Comparative species genetics

LEVI, H. W. and evolutionary problems. Generics, 52(1): 203-215.

1959. The spider genus Latrodectus (Araneae, Theridiidae). Trans. Amer. Micros. Soc., $78:$ 7-43.

1966. The Three species of Latrodectus (Araneae), found in Israel. J. Zool. Lond., 150 : 427-432.

Manwell, C. And C. M. Ann Baker.

1963. A sibling species of sea cucumber discovered by starch gel electrophoresis. Comp. Biochem. Physiol., 10: 39-53.

McCrone, J. D. And H. W. Levi.

1964. North American widow spiders of the Latrodectus curacaviensis group (Araneae: Theridiidae). Psyche. $71(1):$ 12-27. 
Rabaey, M. and G. Verriest.

1957-58. Etude comparative de l' hémolymphe de 33 espèces d' araignées par microélectrophorèse sur gélose. Intérêt systématique de cette méthode. Ann. Soc. zool. Belg., 88 (1957-58): 373-383.

SZLEP, R.

1965. The web-spinning process and web-structure of Latrodectus tredecimguttatus, L. pallidus and L. revivensis. Proc. Zool. Soc. Lond., 145 (1) : 75-89. 


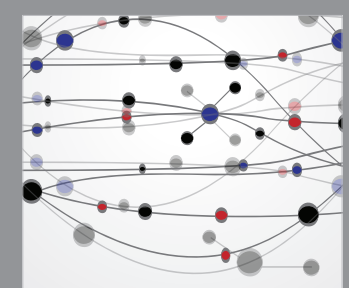

The Scientific World Journal
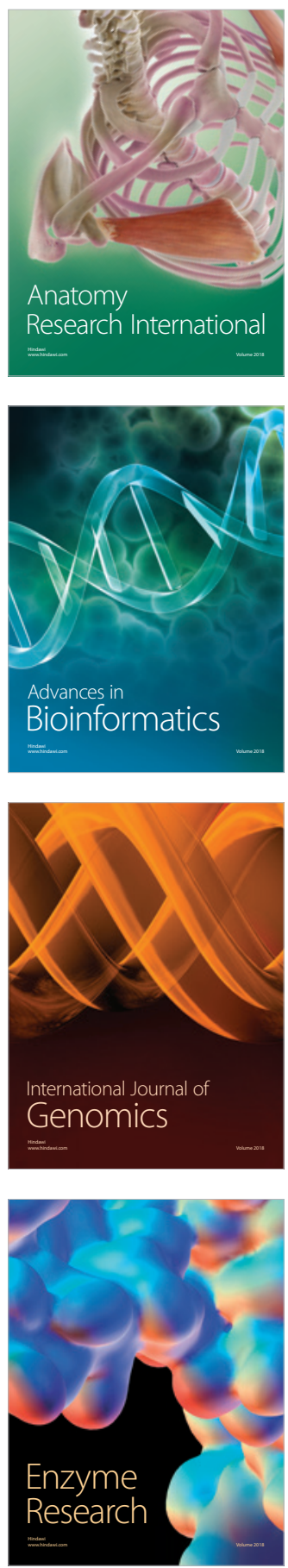
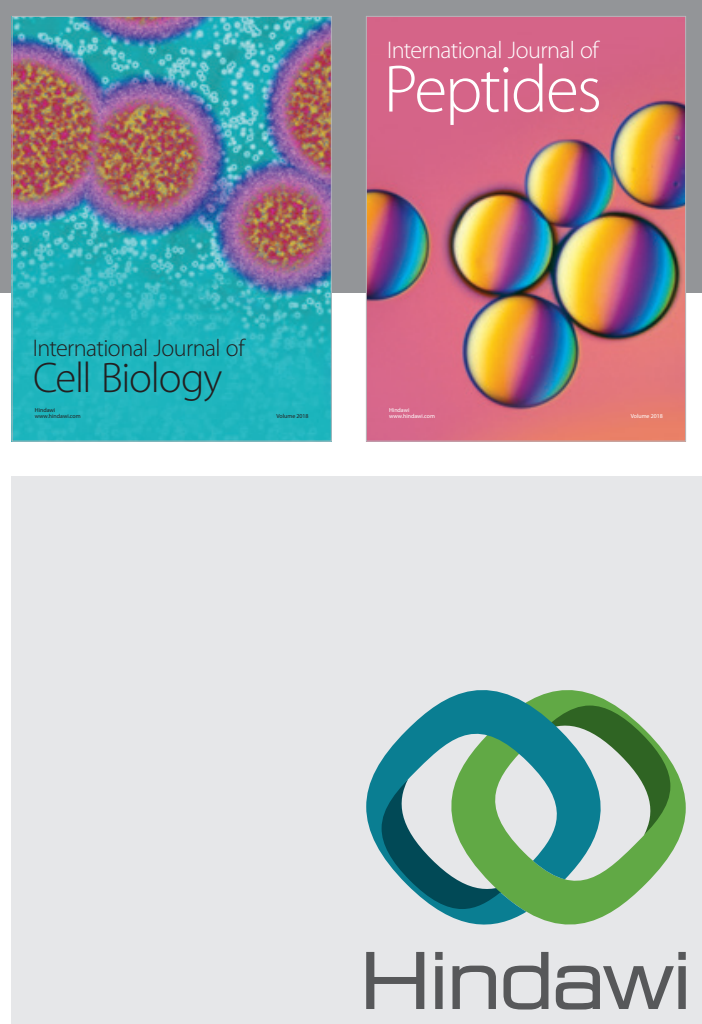

Submit your manuscripts at

www.hindawi.com
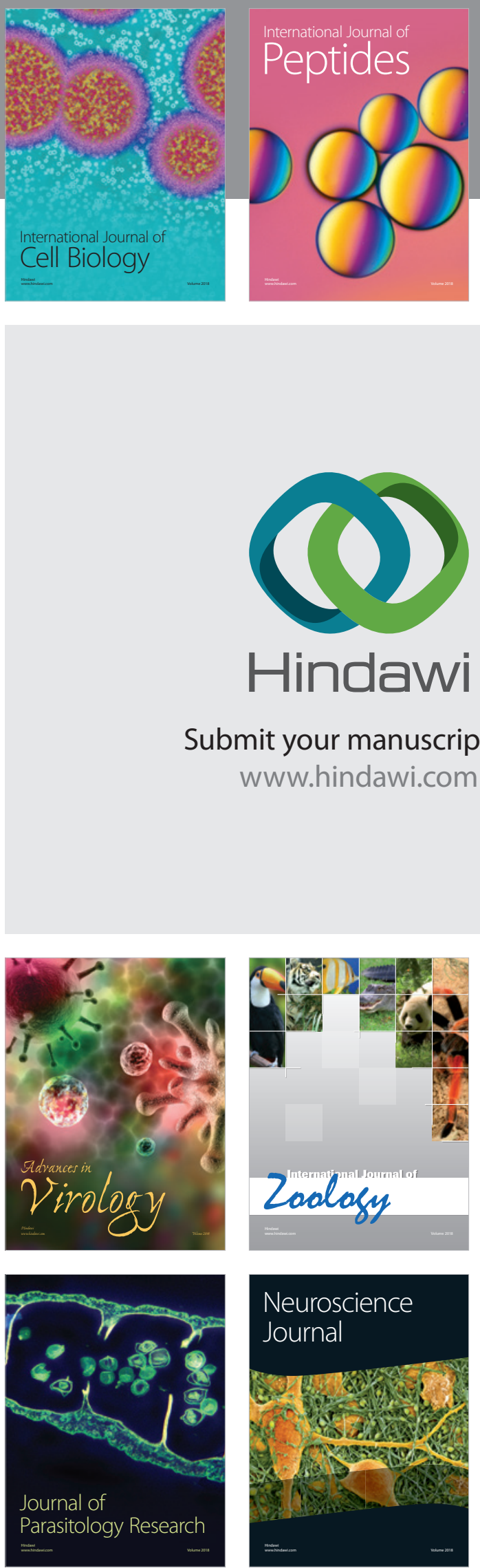
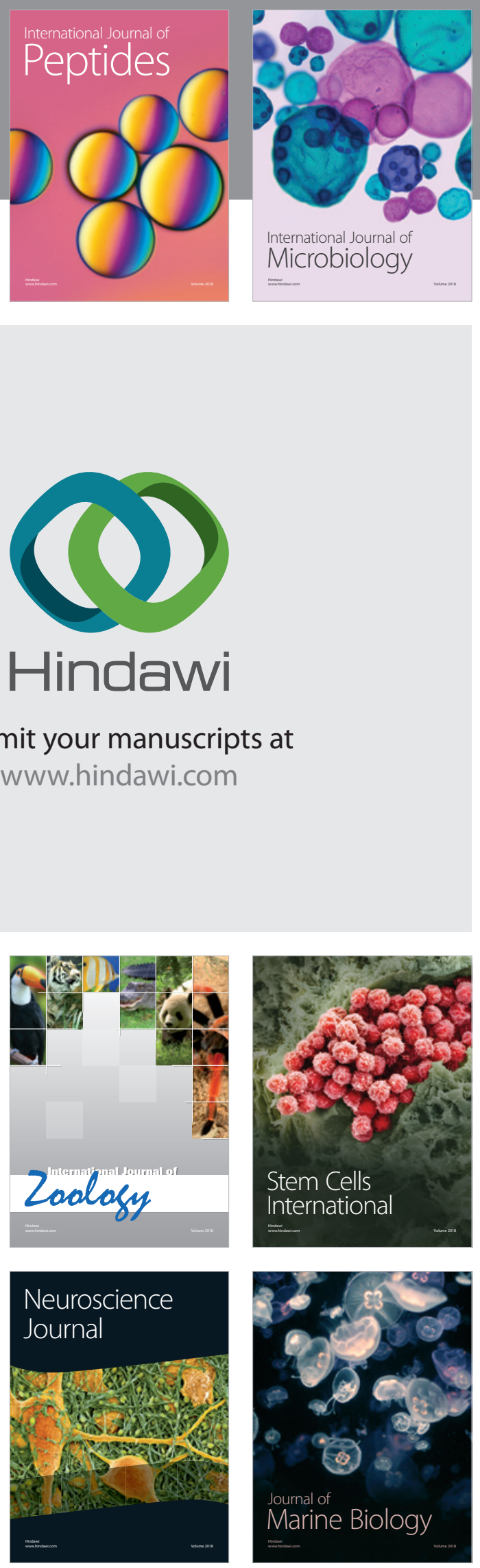
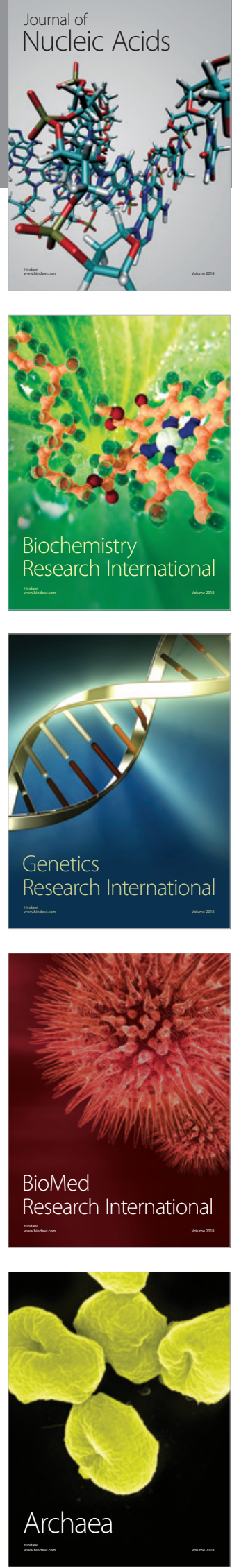